\title{
Efficiency of Advanced Systems for Minimum and Unconventional Tillage for Maize Production on Slope Lands
}

\author{
Petar Dimitrov Dimitrov ${ }^{1}$, Hristo Ivanov Beloev ${ }^{2}$, Gergana Slavova Kuncheva ${ }^{1}$ \\ ${ }^{1}$ Department of Soil Science, Institute of Soil Science, Agrotechnologies and Plant Protection, Sofia, Bulgaria \\ ${ }^{2}$ Department of Agricultural Machinery, University of Ruse, Ruse, Bulgaria
}

Email address:

pddimitrov@dir.bg (P. D. Dimitrov), hbeloev@uni-ruse.bg (H. I. Beloev), g1nikolova@abv.bg (G. S. Kuncheva)

\section{To cite this article:}

Petar Dimitrov Dimitrov, Hristo Ivanov Beloev, Gergana Slavova Kuncheva. Efficiency of Advanced Systems for Minimum and Unconventional Tillage for Maize Production on Slope Lands. International Journal of Economics, Finance and Management Sciences. Vol. 5, No. 5, 2017, pp. 263-267. doi: 10.11648/j.ijefm.20170505.15

Received: August 2, 2017; Accepted: August 25, 2017; Published: October 13, 2017

\begin{abstract}
The consequences of water erosion processes in arable lands are reduction of the root layer, deterioration of soil structure, lower water retention capacity of the soil and loss of nutrients and organic matter, and final result, reduction of soil fertility. To combat water erosion on slope lands were created advanced systems for minimum and unconventional tillage for cultivation of maize on slope lands. This study examines the economic efficiency of these systems, included the impact of these treatments on the yield of crops and their conservation effect.
\end{abstract}

Keywords: Water Erosion, Minimum Tillage, Erosion Control Efficiency, Economic Efficiency

\section{Introduction}

The consequences of the degradation processes on water erosion and the loss of soil organic matter are of great importance for the economic life, and the damages caused by them are enormous, which necessitates the application of a system of erosion control measures.

Of the whole complex of erosion control measures (practices), the most important for the protection of the agricultural lands from the soil water erosion are the agrotechnological ones, carried out with the help of various erosion control technological processes, methods and technologies. Their advantages are low cost, easy implementation and reduction of hydro-erosion processes as soon as they are applied [2,3].

For these reasons, in ISSAPP "Nikola Pushkarov" - Sofia, in cooperation with the Ruse University "Angel Kanchev", there are designed and developed advanced systems for minimum and unconventional soil tillage (soil protection technologies for minimum soil tillage with the inclusion of technological operation vertical and surface mulching with compost), to limit the degradation processes (water erosion and loss of organic matter) in the cultivation of maize and wheat on sloping agricultural lands.

The aim of the present work is to establish the economic efficiency of the advanced soil protection technologies for minimum and unconventional soil tillage for maize production on sloping agricultural lands on the basis of the obtained experimental results.

\section{Method}

The study was conducted in the territory of the village of Trastenik, Ruse region in the experimental field of the Institute of Soil Science "Nikola Pushkarov" Sofia, on a moderate eroded calcareus chernozem, with a slope of $5^{\circ}$ $(8.7 \%)$.

A field experiments were conducted on block method, in four variants, with four replicates. The variants of the experiments are:

$\mathrm{d}_{0}$ - maize plots, grown by using conventional technology, applied along the slope - control;

$\mathrm{d}_{1}$ - maize plots, grown by using conventional technology applied across the slope;

$\mathrm{d}_{2}$ - maize plots, grown by using erosion control technology, including surface mulching with ready compost, 
all operations applied across the slope;

$\mathrm{d}_{3}$ - maize plots, grown by erosion control technology, including soil tillage without reversing the layer - loosening and soil protection operation vertical mulching with ready compost, making slits with ducts, along with sowing and digging and furrowing along the hilling (advanced technology for minimum unconventional soil tillage) applied across the slope.

During the experimental period, variants $d_{0}$ and $d_{1}$ have been subject to the same soil tillage systems - conventional grain maize processing technology. The difference between these variants is only the direction of their implementation. In the first variant it is along the slope, and in the second one in the cross direction. In the same transverse direction, the technological operations were carried out in the third variant, and before the pre-sowing treatments, surface mulch with ready compost (3000-4000 $\mathrm{kg} / \mathrm{ha})$, waste product from mushroom production was applied. In the variant $d_{3}$, the process involves soil-protection measures such as basic soil tillage without reversing the layer - cultivation, vertical mulching with compost, implementation slits with ducts, along with sowing and digging, and furrowing along the hilling. In this case were applied, the chisel cultivator CP-9, a specialized machine for vertical mulching, the hoeing devices mounted on the SPC-6 pneumatic sowing frame and the KRN-4.2 cultivator, and a combined (makiung slits and ducts) cultivator KRN 4.2 (Figure 1).

Annually, on the area of experiment, were carried out agro-technical, erosion studies and economic evaluation.

Erosion indicators (volume of surface water runoff and quantity of eroded soil) are determined by the landfill method with drainage sites.

The yield over the years has been established by an indirect method, taking average samples of each variant, each time by weighing the cobs from the reporting area $\left(100 \mathrm{~m}^{2}\right)$. Primary and additional production is determined at standard moisture.

The economic evaluation of advanced erosion control technologies for the production of grain maize on sloping agricultural lands was carried out according to a standard methodology, taking into account the obtained yields from crops, as well as the costs for labor and materials. The productivity of agricultural machinery was determined on the basis of field experiments, and production costs were calculated on own land and agricultural machinery.
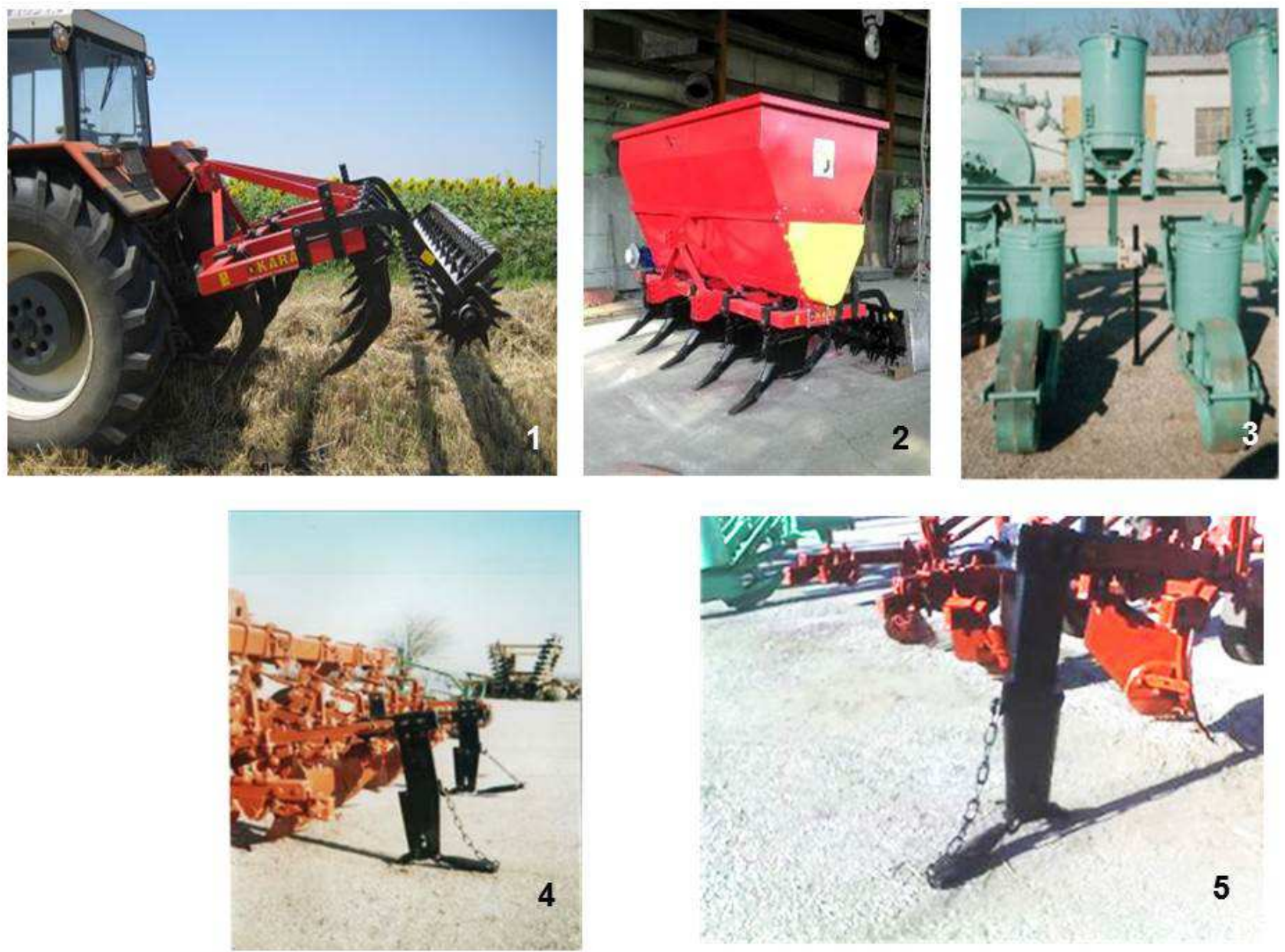

Figure 1. Machines and devices for the implementation of the advanced soil protection technology for minimum and unconventional soil tillage: 1- chisel cultivator CP-9; 2- specialized machine for vertical mulching; 3- sowing machine SPC 6 with slitting device; 4 - cultivator KRN 4.2 with cutting work bodies; 5 - A combination grooming device for implementation slits with ducts attached on cultivator KRN 4.2. 
In determining the annual profitability of individual soil protection methods and technologies, the costs for their implementation at current prices and norms have been calculated first. In determining total costs, account is taken, above all, of the data from the annual poll report and the approved plan account for the year concerned. Secondly, the conservation of soil fertility as a result of the application of these erosion control methods and their income in higher yields and the significantly lower nutrient losses from the soil. In order to determine the last index, our scientists have developed the value of the soil, and especially of the nutrients - available nitrogen, phosphorus and potassium in one tonne soil, with an average value for the country at levels of $6.55 \mathrm{BGN} / \mathrm{t}$ [7]. However, this is not the average monetary value of the soil in Bulgaria, the cost of which depends on a number of different factors and for which no methods have been found yet. Although strongly diminished, this value gives some insight into the cost-effectiveness of soil protection methods and technologies for growing grain maize on slope lands applied to protect soil of water erosion and loss of soil organic matter [5].

For the purpose of determining cost-effectiveness, were used the method and formulas to determine the cost of performing a given mechanical work on a machine-tractor unit [8].

\section{Result}

As a globally strategically important crop, maize has also grown in sown areas with over 450000 ha (National Development Strategy for Grain Production). This is why the yields of grain maize are one of the main indicators of agrotechnical and economic efficiency in applied soil protection technologies [5]. Table 1 presents the results of the reported average yields of maize grain by years and average for the period 2012 - 2014. They show that the yields of this crop are highest in $\mathrm{d}_{3}$, using soil protection technology for minimum and unconventional soil tillage, which includes the methods of vertical mulching with compost, implementation slits with ducts in various stages of the production cycle and furrowing and cutting, simultaneously with the technological operation hilling. On average, for the three-year study period, it was $17.6 \%(979.67 \mathrm{~kg} / \mathrm{ha})$ higher than that of a control plots with a conventionally grown crop along the slope. In variant $\mathrm{d}_{2}$ with a conventional soil tillage system and surface mulching with ready compost, the increase in average maize yield was lower $-9.3 \%$ (by $515.0 \mathrm{~kg} / \mathrm{ha}$ ) and in variant $\mathrm{d}_{1}$ it is $6.0 \%$ and $332.0 \mathrm{~kg} / \mathrm{ha}$.

Table 1. Grain yield, 2012-2014y.

\begin{tabular}{|c|c|c|c|c|c|c|c|c|}
\hline \multirow{3}{*}{ Variants } & \multicolumn{2}{|l|}{ Yield } & \multicolumn{2}{|l|}{ Yield } & \multicolumn{2}{|l|}{ Yield } & \multicolumn{2}{|l|}{ Yield } \\
\hline & $\mathrm{kg} / \mathrm{ha}$ & $\%$ & $\mathrm{~kg} / \mathrm{ha}$ & $\%$ & $\mathrm{~kg} / \mathrm{ha}$ & $\%$ & kg/ha & $\%$ \\
\hline & 2012 & & 2013 & & 2014 & & 2012-2014 & \\
\hline$d_{0}$ & 2885,0 & 100,0 & 6753,0 & 100,0 & 7067,0 & 100,0 & 5568,33 & 100,0 \\
\hline$d_{2}$ & 3274,0 & 113,5 & 7328,0 & 109,3 & 7648,0 & 108,2 & 6083,33 & 109,3 \\
\hline $\mathbf{d}_{3}$ & 3443,0 & 119,3 & 7937,0 & 117,5 & 8264,0 & 116,9 & 6548,00 & 117,6 \\
\hline
\end{tabular}

ANOVA (\%): HSD [.05]=4.06; HSD [.01] $=5.81, \mathrm{~d}_{0}$ vs $\mathrm{d}_{1} \mathrm{P}<0.01, \mathrm{~d}_{0}$ vs $\mathrm{d}_{2} \mathrm{P}<0.01, \mathrm{~d}_{0}$ vs $\mathrm{d}_{3} \mathrm{P}<0.01, \mathrm{~d}_{1}$ vs $\mathrm{d}_{2}$ nonsignificant, $\mathrm{d}_{1}$ vs $\mathrm{d}_{3} \mathrm{P}<0.01, \mathrm{~d}_{2}$ vs $\mathrm{d}_{3} \mathrm{P}<0.01$

Table 2. Total volume of surface water runoff and amount of eroded soil 2012-2014.

\begin{tabular}{|c|c|c|c|c|c|c|c|c|c|}
\hline \multirow{3}{*}{ Date } & \multirow{3}{*}{ Rain $1 / \mathbf{m}^{2}$} & \multicolumn{4}{|c|}{ Surface water runoff $\mathrm{m}^{3} / \mathrm{ha}$} & \multicolumn{4}{|c|}{ Eroded soil kg/ha } \\
\hline & & \multicolumn{4}{|c|}{ Variant } & \multicolumn{4}{|c|}{ Variant } \\
\hline & & $d_{0}$ & $\mathbf{d}_{1}$ & $\mathbf{d}_{2}$ & $\mathbf{d}_{3}$ & $\mathbf{d}_{0}$ & $d_{1}$ & $\mathbf{d}_{2}$ & $d_{3}$ \\
\hline 28.05 .12 & 22.0 & 225.252 & 123.630 & 116.768 & 43.960 & 3622.0 & 1446.8 & 1378.0 & 168.5 \\
\hline 06.08 .12 & 15.5 & 141.907 & 73.913 & 70.909 & 26.733 & 1927.8 & 682.2 & 655.9 & 83.9 \\
\hline 12.08 .12 & 18.0 & 174.820 & 93.762 & 90.101 & 33.664 & 2598.6 & 981.4 & 939.0 & 116.5 \\
\hline 27.08 .12 & 12.5 & 128.957 & 65.217 & 62.828 & 23.960 & 1855.0 & 648.1 & 617.9 & 76.4 \\
\hline For 2012 y. & 68.0 & 670.936 & 356.522 & 340.606 & 128.317 & 10003.4 & 3758.5 & 3590.8 & 445.3 \\
\hline 13.06 .13 & 12.0 & 157.183 & 89.492 & 79.661 & 29.533 & 2054.1 & 744.2 & 669.8 & 88.8 \\
\hline 08.07 .13 & 28.5 & 190.775 & 114.509 & 102.203 & 37.570 & 2899.1 & 1116.9 & 1044.1 & 128.6 \\
\hline For 2013 y. & 68.5 & 530.071 & 309.764 & 277.796 & 102.243 & 7613.2 & 2876.0 & 2651.0 & 334.6 \\
\hline 14.05 .14 & 18.0 & 230.365 & 141.151 & 127.135 & 45.236 & 3260.2 & 1293.8 & 1185.6 & 145.3 \\
\hline 31.05 .14 & 54.0 & 165.547 & 93.237 & 83.027 & 31.099 & 2112.9 & 771.1 & 699.5 & 92.1 \\
\hline 18.06 .14 & 30.0 & 200.548 & 117.410 & 104.432 & 39.267 & 3102.5 & 1188.9 & 1104.2 & 136.2 \\
\hline For $2014 \mathrm{y}$ & 102.0 & 596.496 & 351.798 & 314.594 & 115.602 & 8475.6 & 3253.8 & 2989.3 & 373.6 \\
\hline
\end{tabular}

ANOVA Surface water runoff; $\mathrm{P}<0.0001 ; \operatorname{HSD}[0.05]=27.62 ;$ HSD [0.01] $=34.26 ; \mathrm{d}_{0}$ vs $\mathrm{d}_{1} \mathrm{P}<0.01 ; \mathrm{d}_{0}$ vs $\mathrm{d}_{2} \mathrm{P}<0.01 ; \mathrm{d}_{0}$ vs $\mathrm{d}_{3} \mathrm{P}<0.01 ; \mathrm{d}_{1}$ vs $\mathrm{d}_{2}$ nonsignificant; $\mathrm{d}_{1}$ vs $\mathrm{d}_{3} \mathrm{P}<0.01 ; \mathrm{d}_{2}$ vs d $_{3} \mathrm{P}<0.01$

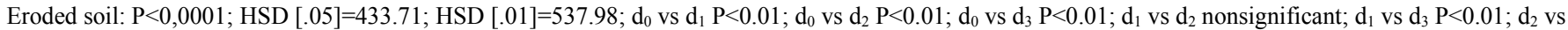
$\mathrm{d}_{3} \mathrm{P}<0.01$

The applied improved soil protection technologies for minimum and unconventional soil tillage in the cultivation of grain maize on slope arable lands have a higher erosion control effect due to increased soil infiltration capacity and 
improved soil protection effect of vegetation and plant debris. This reflects not only the volume of surface water runoff, the amount of eroded soil, but also the amounts of nutrients and humus substances exported from water erosion.

When applying the proposed improved soil protection technology for minimum and unconventional soil tillage, the average annual surface water runoff decreases from 5.2 to 5.4 times and those of the eroded soil from 21.5 to 24.3 times, compared to maize plots grown by conventional technology, applied along the slope and this effect being maintained throughout the whole production cycle. This reduction of erosion indexes is 2.1 times in the surface runoff and 3.0 times in the soil loss (Table 2) in $\mathrm{d}_{2}$-with application of surface mulch. Losses of mineral nitrogen, available forms of phosphorus, potassium and loss of organic matter are 6.27, 11.5, 6.28 and 17.37 times lower with the application of the advanced technology for minimum tillage with vertical mulching compared to the losses of these substances in the course of the water erosion processes in plots, grown by conventional technologies, applied along the slope (control) (Figure 2). As a result of the use of the advanced soil protection technology including the soil erosion techniques, vertical mulching with compost, making slits with ducts in various stages of the production cycle and furrowing and cutting, simultaneously with the technological operation hilling, the yield increases significantly; the amount of eroded soil and nutrients exported with it decreases. As a result, using corn grain prices and the monetary value of nutrients in tons of soil, additional income is obtained as follows: for 2012 218,85 BGN/ha, for 2013 - 379,20 BGN/ha, for 2014 - 388,23 $\mathrm{BGN} / \mathrm{ha}$. The average value of this indicator for the three-year period is $328.76 \mathrm{BGN} / \mathrm{ha}$. Taking these values into account and taking into account the extra costs incurred, the net income per year is as follows: for the first year - 208.75 BGN/ha, for the second - $322.95 \mathrm{BGN} / \mathrm{ha}$, for the third - $329.58 \mathrm{BGN} / \mathrm{ha}$. The average economic efficiency of application of the soil protection technology is $273.66 \mathrm{BGN} / \mathrm{ha}$, with a profitability of 249\% (Table 3).

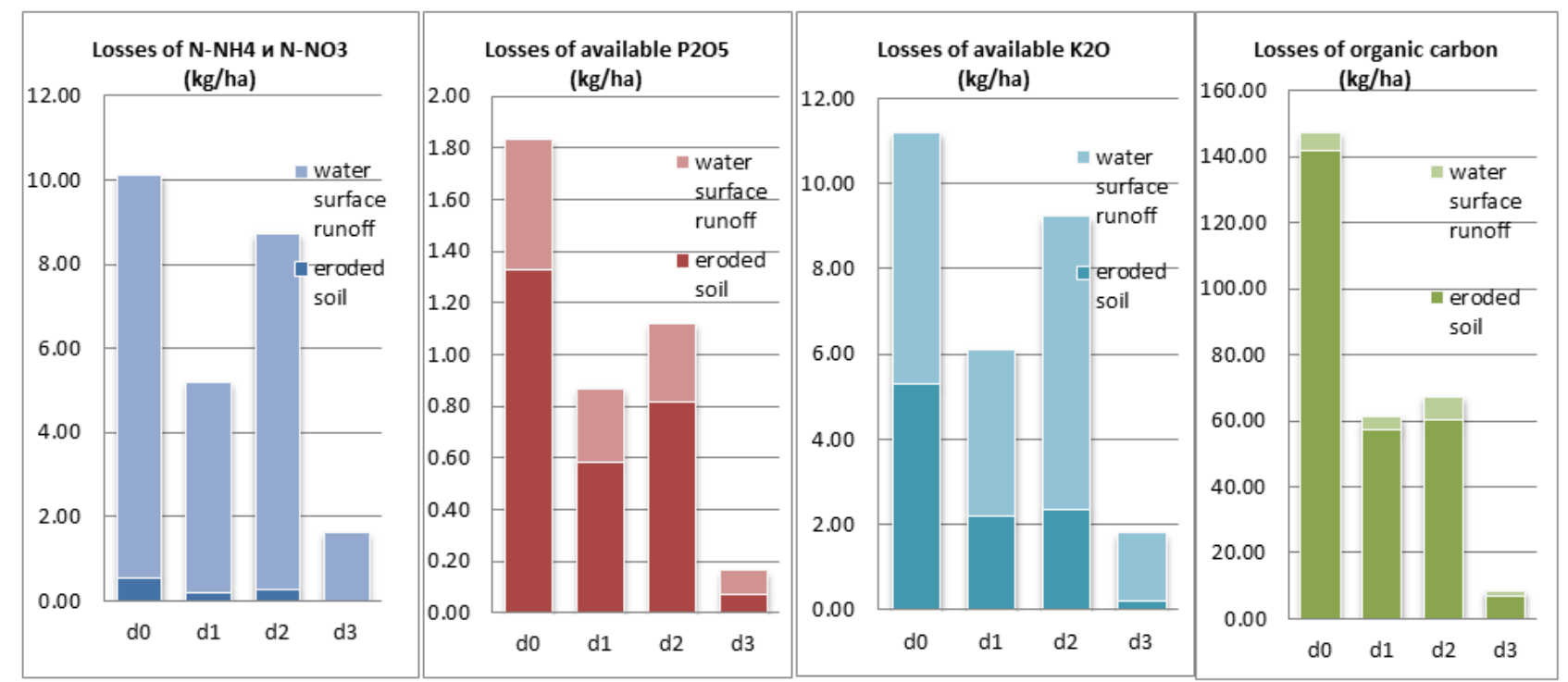

Figure 2. Losses of available forms of $\mathrm{N}\left(\mathrm{N}-\mathrm{NO} 3-+\mathrm{N}-\mathrm{NH} 4+\right.$ ), $\mathrm{P}_{2} \mathrm{O}_{5}, \mathrm{~K}_{2} \mathrm{O}$, organic carbon with eroded soil and surface water runoff (kg / ha) on average over the three years (2012-2014).

Table 3. Economic efficiency of advanced soil protection technology for minimum and unconventional soil tillage for growing maize on slope agricultural lands, 2012-2014.

\begin{tabular}{lllll}
\hline \multirow{2}{*}{ Indexes } & Units & Values & & \\
\cline { 3 - 5 } & & $\mathbf{2 0 1 2} \mathbf{y}$. & $\mathbf{2 0 1 3}$ y. & $\mathbf{2 0 1 4}$ y. \\
\hline Additional costs & BGN/ha & 50,40 & 56,25 & 58,65 \\
Additional revenue & BGN/ha & 218,85 & 379,20 & 38,23 \\
Net income & BGN/ha & 208,75 & 322,95 & 328,10 \\
\hline
\end{tabular}

\section{Conclusion}

1. The advanced soil protection technology for minimum and unconventional soil tillage for growing grain maize on sloping terrains has significant economic efficiency, consisting in increasing yields and realizing net monetary income as well as preserving soil and soil fertility.

2. The average yield of maize grain using this technology, that includes soil-protection measures soil loosening such as basic treatment, vertical mulching with ready compost, implementation slits with ducts, along with sowing and digging, and furrowing along the hilling in the vegetation of the plants are $17.6 \%$ (by $979.7 \mathrm{~kg} / \mathrm{ha}$ ) higher than the yields of the areas conventionally cultivated along the slope.

3. When applying the improved soil protection technology, losses of eroded soil are from 21.5 to 24.3 times lower, and the volume of surface runoff is from 5.2 to 5.4 times lower compared to the control variant. The reduction of mineral nitrogen losses, available forms of phosphorus and potassium, 
and organic carbon from the hydro-erosion processes are respectively $6.27,11.50,6.28$ and 17.37 times compared to the conventionally grown maize plots along the slope.

4. The net income of grain maize cultivated on inclined terrains using the proposed soil protection technology varies between the years of study from BGN 208.75 / ha to BGN 329.58 / ha and an average for the period 2012-2014 is $273.66 \mathrm{lv} /$ ha (with profitability $24.9 \%$ ).

\section{References}

[1] Beloev Hr, P. Dimitrov, N. Markov, Gr. Tsankova, 2008. Technologies for minimum soil tillage on slope lands in the conditions of sustainable agriculture. Agricultural Academy Sofia.

[2] Dimitrov P., H. Beloev, E. Tzvetkova, D. Ilieva, K. Stoyanov, G. Georgiev, 2009. Investigation of the soil protection method vertical mulching for growing wheat on sloping terrains. International Conference "Soil Treatment and Ecology" ISTRO, Albena, p. 42-48.

[3] Dimitrov P., H. Beloev, K. Stoyanov, D. Ilieva, G. Georgiev, 2009. Investigation of the efficiency of the technology for minimum soil tillage in the cultivation of grain maize on slope arable lands., International conference "Processing of Soil and ecology "- ISTRO, Albena, p. 49-55.

[4] Dimitrov, P., Hr. Beloev, T. Trifonova, S. Russeva, K. Stoyanov, D. Ilieva, G. Kuncheva. 2016. Improved soil protection technologies for minimum and unconventional soil tillage on inclined terrains, Rousse University Publishing House "A. Kunchev ", Rousse, 62 pp.

[5] Dimitrov PD 2016. Technology and system of machines for soil protection agriculture. Dissertation work for awarding a degree Doctor of Science, Rousse University, Rousse, 375 p.

[6] Kuncheva, G. 2016. Author of the dissertation thesis for the award of educational and scientific degree $\mathrm{PhD}$ on topic "Soil protection and agricultural efficiency of advanced minimal and unconventional erosion control tillage when growing crops on slope lands ". Sofia, $147 \mathrm{pp}$.

[7] Lazarov A. L., D. Nekova, 2005. Economic assessment of the average annual losses of basic nutrients from surface water erosion. Scientific papers from a national conference with international participation, Sofia, pp. 377-380.

[8] Naneva A., A. Tashev. 1976. Economics and Organization of Agriculture. Printing base of VTU, Rousse. Soil protection and agricultural efficiency of advanced minimum and unconventional erosion control tillage when growing crops on slope lands.

[9] Rousseva, S. 2007. Capacity Building for Sustainable Land Management in Bulgaria" Stocktaking of land degradation in agriculture Discussion Report.

[10] Rousseva S., 2013. Factors and rates of soil erosion in the Balkan Peninsula. Journal of Balkan Ecology, 16 (2).

\section{Biography}

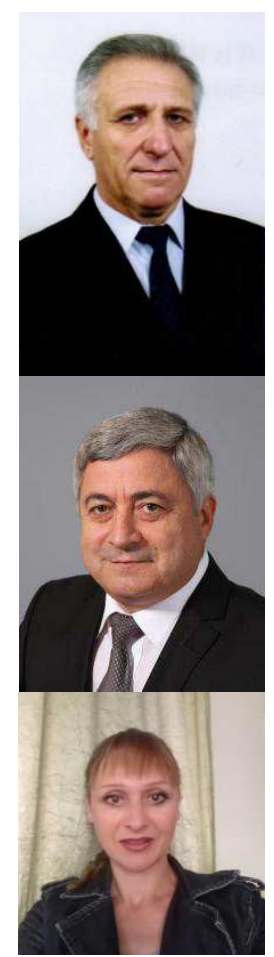

Petar Dimitrov Dimitrov, Scentific section "Erosion of soil", Institute of Soil Science, Agrotechnologies and Plant Protection "Nikola Pushkarov" - Sofia.

Hristo Ivanov Beloev, "Angel Kanchev" University - Ruse.

Gergana Slavova Kuncheva, Scentific section "Erosion of soil", Institute of Soil Science, Agrotechnologies and Plant Protection "Nikola Pushkarov" - Sofia. 